\title{
JMLE
}

The National Association for Media Literacy Education's

Journal of Media Literacy Education 11 (1), 52 - 74

https://doi.org/10.23860/JMLE-2019-11-1-3

\section{Developing Student Critical Consciousness: Twitter as a Tool to Apply Critical Literacy in the English Classroom}

\author{
Joshua P. Kunnath and Arika Jackson \\ California State University, Fresno
}

\begin{abstract}
As young people today are flooded with information from a multitude of sources, they must be prepared to perceive the potentially oppressive and nefarious nature of many texts. Critical literacy is a theory and strategy that allows young people, along with people of all ages, to achieve just this; however, teachers often experience difficulties implementing and guiding students in taking crucial action steps in the classroom. This exploratory action research case study was conducted to address these concerns, as a teacher utilized Twitter to implement critical literacy and guide 32 ethnically diverse eleventh grade students in applying critical literacy in an AP English Language and Composition class. The study was conducted within a unit on American Transcendentalist literature over the course of one month, and the teacher and students used their cell phones inside and outside of the classroom to access Twitter for purposes of research, communication, and interaction. Qualitative methods were used to collect data from student and teacher tweets, reflections, and interviews, which were analyzed with a qualitative conventional content analysis approach. Results showed that Twitter was effective in implementing critical literacy in the classroom. Additionally, multiple affordances included a transformation of teaching and learning in the classroom of study, amplified student voice, increased student engagement, and a potential for student action. Results are discussed in the context of students' achievement of critical action and approach to a state of critical consciousness and may be of interest to the teacher or administrator challenged by critical literacy implementation, curious about critical literacy, or seeking additional technology-infused literacy strategies
\end{abstract}

Keywords: critical literacy, Twitter, English teachers, action research, secondary education

Keywords: critical literacy, Twitter, English teachers, action research, secondary education

President Donald J. Trump, in an April 2017 Oval Office interview with the Financial Times, declared that without his prolific tweeting, he would not have become president of the United States (Barber, Sevastopulo, \& Tett, 2017). With two Twitter handles, over 84 million combined followers, and more than 46,000 
tweets and counting, President Trump has come to exemplify Twitter's potential for impact on today's society. Many Americans share the president's enthusiasm for Twitter, as $24 \%$ of American adults report that they use the social media service, including $48 \%$ of adults aged 18 to 24 (Smith \& Anderson, 2018). And like many types of social media, the majority of users are from younger generations, as the largest cohort of adult users - 40\%-is from ages 18-29 (Statistica.com).

Of course there are many who attempt to use the power of social media to attain personal objectives, but there are even more who simply consume the information. America's youngest generation makes up a significant proportion of the consumers, and they are exposed to more information from an early age than any previous generation. In addition to Twitter and other social media such as Facebook, Snapchat, Instagram, and YouTube, the ubiquity of cellphones and other Web-based devices has led to the inundation of adolescents in a plethora of internetbased content including music, videos, movies, images, and various texts, not to mention traditional print-based texts (Rideout, Foehr, \& Roberts, 2010).

America's youth are sometimes referred to as digital natives because they are most often raised with technologies such as Internet, computers, and other Webbased devices. With this designation, it is often assumed that youth exhibit strong technology skills and particular learning modalities related to these technologies (Prensky, 2001). However, multiple studies have found that young people often lack the skills necessary to effectively assess information accessed online (Junco \& Chickering, 2010; Margaryan, Littlejohn, \& Vojt, 2010; Thompson, 2013; Waycott, Bennett, Kennedy, Dalgarno, \& Gray, 2010). Additionally, these nontraditional texts, along with the more traditional types, often contain misinformation, explicit and implicit biases, and value judgments about which so many of our students are unaware. Unfortunately, teens often lack essential skills to deeply understand texts while avoiding manipulation. Critical literacy is one method to address this issue (McLaughlin \& DeVoogd, 2004b).

\section{Critical Literacy Theory}

Although it defies a single definition, critical literacy is characterized in several common ways. It is often described as a theory and practice of teaching and learning in which literacy is used to promote principles of democracy, equity, and social justice (Freire \& Macedo, 1987; Luke, 2000; Riley, 2015). While Freire and Macedo (1987) were among the first to articulate the principles of the theory, critical literacy largely emerged from Paulo Freire's (1970) work in critical theory and critical pedagogy, articulated in his work Pedagogy of the Oppressed. In the book Freire emphasized the importance of praxis, defined as "reflection and action upon the world in order to transform it" (51). One can infer from Freire's work that effective critical literacy requires praxis. Freire was clear that praxis ideally leads to conscientização, or critical consciousness, described as the development of a critical awareness of the various elements of societal oppression and subsequent action against it (Freire, 1970, 1974; Smith, 1976). In Education for Critical Consciousness, Freire (1974) articulated the importance of critical consciousness when he warned, "If men are unable to perceive critically the themes of their time, 
and thus to intervene actively in reality, they are carried along in the wake of the change" (6).

Another important concept Freire (1970) introduced in his theory of critical pedagogy, and by extension critical literacy, was the importance of the teacherstudent partnership. This partnership, Freire explained, consists of the teacher and students engaged in continual dialogue and mutual learning while being posed with problems related to themselves, the world, and the self-world relationship. The teacher-student partnership is essential to liberate students and teachers from the banking concept of education, described by Freire as the traditional and oppressive system of education similar to "an act of depositing, in which the students are depositories and the teacher is the depositor" (72).

Yet here has been an increasing amount of literature on critical literacy since Paolo Freire. A number of researchers suggest that language instruction is an important component of literacy instruction (Comber, 2011; Gee, 2000; Morrell, 2005; Street, 2003). Bloome, Carter, Christian, Otto and Shuart-Faris (2004) point out that critical literacy calls for students to have the ability to build on their understanding of the world around them, which includes the use of language. This view is supported by Gee $(1989,2005)$, who presented the idea of "discourse" to describe the different ways that individuals and groups use language socially in the world. Gee (2002) suggests that in order for students to "imagine better and more socially just ways of being the world" (190), they must be given opportunities to have meaningful discussions about language and power in order to challenge the systems that oppress them.

Additionally, The New London Group (1996) maintains that the key to critical literacy is helping students understand the representations of semiotic systems and how to restructure these systems to create change. To better understand this concept, Janks' Orientation to Critical Literacy Model can be useful. In this model, Janks suggests that critical literacy teaching is challenging and is not a neutral activity. He offers four interdependent orientations to teaching literacy: domination, access, diversity, and design. Commenting on Janks' model, Comber (2011) highlights that "students need access to academic language in order to question dominant discourses; to use the diversity of their language and life experiences; and to understand the semiotic systems for students to generate new meanings" (8).

\section{Critical Literacy in the Classroom}

In the classroom, critical literacy assists students in determining the purpose and reliability of information, considering those favored and marginalized, exploring multiple perspectives, and taking action. Students are challenged to look beyond the literal message, read between the lines, question the text, observe present and missing information, and consider the influence of the author's context and structure on the reader (McLaughlin \& DeVoogd, 2004b; McLeod \& Vasinda, 2008). Although teachers of critical literacy have similar goals, it is notoriously difficult to implement in the classroom. Limited opportunities for professional development on critical literacy implementation poses challenges, as Behrman 
(2006) explained that a lack of specific instructional strategies often poses problems for teachers attempting to apply critical literacy in their own curriculum. Similarly, Sperry and Baker (2016) argue that educators must raise students' awareness and teach them to critically question media and technology. Sperry and Baker (2016) maintain that when classroom teachers allow students to decode content-rich text, students learn to ask key questions, analyze texts, identify perspectives, and draw conclusions. The National Association for Media Literacy Education developed "Key Questions To Ask When Analyzing Media Messages," which can be used to help students understand the audience and authorship, messages and meanings, and representations and reality. These questions can be used across content areas to teach students the skills and habits of critical literacy (Rogow, 2011).

Furthermore, Luke (2000) posited that the essential complexity and numerous approaches to critical theory precludes any standardized curriculum or streamlined strategies. However, a number of books and studies provide direction in this area. McLaughlin and DeVoogd (2004a) recommended explicitly teaching critical literacy strategies in the context of the curriculum. In their book explaining how to integrate critical literacy in the classroom, McLaughlin and DeVoogd (2004a) described that three major concepts-challenging the text, exploring identities, and seeing beyond the bias - are essential strategies, and they may serve as starting points for teachers in their work. But regardless of the critical literacy approach that teachers employ, researchers often recommend focusing on the teacher's role in the process. Multiple studies recommend that teachers receive professional development to authentically engage in critical literacy themselves, and teacher communities have been found to aid teachers in dealing with the difficulties specific to critical literacy (McLaughlin \& DeVoogd, 2004a; Lee, 2011; Riley, 2015; Stribling, 2008). In fact, Project Look Sharp, a media literacy initiative at Ithaca College, offers professional development online courses to help promote and support educators with the integration of critical literacy in the school curriculum. The project provides free lessons that are geared toward analyzing and evaluating media messages (Project Look Sharp, 2018).

Within the last twenty years a number of studies have focused on the practical nature of critical literacy. In a literature review of 36 articles published between 1999 and 2003 that applied critical literacy to the classroom, Behrman (2006) discovered six types of student activities used by teachers: "(1) reading supplementary texts, (2) reading multiple texts, (3) reading from a resistant perspective, (4) producing counter-texts, (5) conducting student-choice research projects, and (6) taking social action" (482). Despite these findings, Behrman added that ironically, the classroom instruction reviewed was generally authoritative in nature-much different from the democratization goal of critical literacy. In another literature review on the topic, Stribling (2008) found three common critical literacy approaches discussed by authors: critically examining texts, using texts as a vehicle to examine social issues, and using students' lives and experiences as the text. But even those successful with implementation often experienced something Bishop (2014) identified as one of the largest problems of critical literacy: applying theory of action into practice. 


\section{Social Media in the Classroom}

Once thought of in education as taboo, social media has made its way into the classroom as an instructional tool. As noted by Machado and Jiang (2014), educators' recent valuing of social media is likely due to their newfound awareness of its potential to increase student engagement and learning. In fact, the National Education Association's (2010) well-known publication "Preparing 21" Century Students for a Global Society" discussed the importance of technology in fostering what has become known in education as the "Four C's": communication, collaboration, critical thinking, and creativity. As a technological platform that addresses each of the "Four C's," social media clearly plays a role in the preparation of twenty-first century students despite being omitted from the report. Twitter, in particular, has become an increasingly popular social media classroom tool over the past decade. The microblogging service has been around since 2007 and has 313 million monthly active users - $82 \%$ of which actively use the platform on a mobile device (Twitter usage: Company facts, 2016). At the time of the study, Twitter allowed users 140 characters for each message, known as a tweet ${ }^{1}$. It also provides the use of hash tags, represented by the pound sign (\#), which can precede words or phrases to index particular topics. For example, by including \#edchat in a tweet, Twitter users are enabled to find and read the tweets of others interested in education-related discussions. Each user is also presented with a home screen that largely consists of a timeline, presenting the tweets of other users they follow ordered by time. These tweets can then be replied to, favorited (a way to indicate admiration or agreement for a tweet), or retweeted (a way to display a users tweet again to one's own followers, normally to display admiration or agreement).

Twitter has been shown to have numerous positive effects in the classroom. A number of studies have found Twitter to positively affect student engagement in high school and college students (Junco, Elavsky, \& Heiberger, 2013; Junco, Heiberger, \& Loken, 2011; Kassens, 2014; Krutka \& Milton, 2013). Rheingold (2009) found that using Twitter provided his digital journalism students with timely information and a way for his students to meet new people. Barbour and Plough (2009) analyzed the use of social media at a charter school and found the implementation to be effective and favored by both instructors and students. Additionally, Menkhoff, Chay, Bengtsson, Woodard, and Gan (2015) found that among other benefits, Twitter facilitated student collaboration with their teacher and peers, leading to positive learning outcomes.

While multiple studies have found Twitter and other technologies to facilitate democratization in the classroom and transformation of the student role from information consumer to producer (Junco et al., 2011; Krutka \& Milton, 2013; McLeod \& Vasinda, 2008), teachers require training on effective technology integration in the classroom to ensure beneficial results. Mishra and Koehler (2006) suggested that a realistic way to educate teachers on technology integration is for teachers to learn to use the technology themselves. However, they explained that

${ }^{1}$ As of November 7, 2017, Twitter allows 280 characters per tweet (Tsukayama, 2017). 
understanding the fundamentals of technology is no substitute for content knowledge, adding that teachers will have a greater chance of success if they are effectively trained to integrate both content and technology. Further, Junco et al. (2013) found that the effectiveness of Twitter as a pedagogical tool was largely determined by the extent of teachers' own use of Twitter and the interactions with their students via the technology.

In the present study, Twitter served as a tool for the teacher to implement critical literacy in the English curriculum and provide students with a vehicle to address what Bishop (2014) termed as one of the most challenging elements of critical literacy: "designing and undertaking actions focused on social justice outside of the classroom" (55). Thus, the purpose of this action research study was to explore the affordances, or action potential (Bower, 2008), of Twitter in implementing critical literacy in a high school English classroom. In doing so, the study focused on two major concerns expressed in the literature: critical literacy implementation and critical literacy action steps. This purpose was reflected in a single guiding research question: What affordances can Twitter provide the teaching and learning of critical literacy in the English classroom?

\section{METHOD}

Action research, a tool that allows educators to solve real-world problems to make a difference in their classrooms (Stringer, 1999), was selected as a methodology to enable the teacher and lead researcher the freedom to examine and improve his own teaching practice with a hands-on approach (Ferrance, 2000). Stringer's suggested "look, think, act" cyclical approach to action research was used in which the teacher/researcher engaged in an iterative and cyclical process of data collection; interpretation and analysis; and planning, implementing, and evaluating. Action research was deemed particularly appropriate for the study because it parallels the examining and empowering objectives of critical literacy.

A qualitative case study design was used to deeply explore the affordances of Twitter in teaching critical literacy. Researchers followed Creswell's (2007) recommendations for conducting a case study design by determining the appropriateness of the case study approach, identifying it as an individual case, collecting extensive data from multiple sources, conducting holistic analysis of the case, and interpreting the meaning of the case.

\section{Site and Participants}

The study was conducted by two researchers: the lead researcher and teacher, who was a White male in his seventh year teaching, and the co-researcher, a Black female elementary school teacher in a neighboring school district with 18 years of experience in education. The researchers used purposive extreme case sampling 2 to select the lead researcher's Advanced Placement (AP) English

2 A type of purposive sampling in which the sample selected is unusual in some way (Palinkas et al., 2015). 
Language and Composition class for participation in the study (Palinkas et al., 2015). The class, composed of some of the school's highest motivated and achieving students, allowed the researchers to minimize confounding variables. The teacher knew that the class would employ greater effort, motivation, and focus than his other classes, allowing him to focus on the goals of the study and minimize tangential teacher tasks such as classroom management. To be clear, the class was not chosen because the students were thought to have the most to gain from the aims of the study. Rather, the selection decision was made because researchers felt the teacher would have the greatest chance of success in teaching and implementing the unit for the first time.

The class was comprised of 32 ethnically diverse eleventh grade high school students-13 males and 19 females. It was the teacher and lead researcher's second year teaching the particular course and first time utilizing Twitter in the classroom. The study was conducted in his English classroom, which was located in a mid-size urban California high school with a student body that was approximately $66 \%$ Hispanic, 21\% White, and 5\% Black.

\section{Procedure}

The study was conducted within a unit on American Transcendentalist literature over the course of one month. The teacher and students used their cell phones inside and outside of the classroom to access Twitter throughout the unit. To begin, all participants created a new Twitter account to be used specifically for the class. They then followed one another on Twitter so that all class-related tweets would appear on the Twitter feed of each participant. The teacher began instruction by teaching students basic expectations and guidelines for Twitter use, including elements of digital citizenship, appropriate writing voice, and content-based dialogue strategies. The researchers recognized that some may view this type of norming — or even the required use of Twitter - as antithetical to basic tenets of critical literacy and critical theory, similar to Behrman's (2006) criticisms of past studies. However, the researchers felt these types of requirements were crucial and necessary in order to enable students with safe and effective use of a technology that could subsequently empower them above and beyond the limits of the traditional classroom.

Students were next taught about critical literacy theory and guided in its application in two practice texts. Once students gained a basic understanding of the theory and a satisfactory skill in its application, the teacher proceeded to lead students to use Twitter to apply the principles of critical literacy to the content. The curriculum consisted of excerpts of three American Transcendentalist texts: Ralph Waldo Emerson's "Nature" and "Self-Reliance" and Henry David Thoreau's "Resistance to Civil Government." Additionally, students read Ken Kesey's novel One Flew Over the Cuckoo's Nest as a supplementary text outside of the classroom. Learning targets for the unit included reading texts for understanding, analysis of major themes, and analysis of rhetorical strategies.

Twitter was used as a teaching tool at each phase of the unit. During each class period, the teacher combined traditional instructional techniques such as 
lecture, discussion, modeling, think-pair-share, close reading, and text analysis with the use of four major Twitter activities to increase interactive guided practice. One activity was five-minute explorations, which the teacher used at the beginning of the unit and prior to each new text to provide students with contextual information and to activate their prior knowledge. Students were asked to search about the topic on Twitter and tweet one significant finding within five minutes. To do so, students entered terms they felt were relevant to the topic into the Twitter search function and viewed Tweets on the subject. For example, when conducting a five-minute exploration on Transcendentalism, some students started by entering the term Transcendentalism. Based on information found in their initial tweet findings, some then searched for names such as Walt Whitman and Ralph Waldo Emerson. In some cases, this led to subsequent searches on findings on topics such as "SelfReliance" and Leaves of Grass. Students finished by summarizing their findings in a tweet by the end of the five minutes.

Another Twitter activity was news story analysis, which tasked students with finding a recent news story on Twitter and using critical literacy to tweet a response. Students could find news stories by either searching for stories in the Twitter search function or by viewing trending stories in the Twitter search screen. After reading the story, students' tweets were to apply to a critical literacy concept of challenging the text, exploring identities, or seeing beyond the bias (McLaughlin \& DeVoogd, 2004a).

In the literary analysis activity, students were tasked with using critical literacy to analyze a text they were currently reading with the help of Twitter to discover additional understanding and context of the text. Students used Twitter to research individual terms, concepts, and background information of a text to better understand the text on a literal level. After doing so, they again tweeted an application of one of the three basic concepts of critical literacy, as described above.

Finally, Twitter reflection was an activity in which students were asked to reflect on the effectiveness of Twitter to achieve the unit goals. Each activity, all of which required at least one student tweet, was subsequently discussed in small groups and then with the whole class. Table 1 displays example tweets for each Twitter activity.

Assignment tweets were used as assignments inside and outside of the classroom. These tweets were used to increase independent practice and student learning time for learning targets, critical literacy, or a combination of both. For indexing purposes, students included a common class hashtag in each assignment tweet. Students were often asked to use the hashtag or the class Twitter page to read and reply to classmate tweets. Table 2 displays each of the 20 assignment tweet prompts.

\section{Data Collection}

Data were collected in the form of student assignment tweets, student and teacher reflections, student focus groups, and student interviews. Student and teacher reflections were made at the end of each class period. In two to five minutes, students reflected on their Twitter use for learning the learning targets, while the 
teacher reflected on the success of each lesson, needed modifications, and other significant observations. Upon completion of the unit, the teacher randomly divided students into four different focus groups of eight students each to provide further depth to the data on Twitter's use in learning about critical literacy, lasting

Table 1

Type of Twitter Activity, Number of Required Tweets, and Student Examples

\begin{tabular}{lll}
\hline $\begin{array}{l}\text { Type of } \\
\text { Twitter } \\
\text { Activity }\end{array}$ & $\begin{array}{l}\text { Required } \\
\text { Tweets }\end{array}$ & Example Student Tweet \\
\hline $\begin{array}{l}\text { Five-minute } \\
\text { exploration }\end{array}$ & 4 & $\begin{array}{l}\text { "Whitman was between Transcendentalism \& Realism and } \\
\text { incorporated both views in his works. He was aka the "father of } \\
\text { free verse' " }\end{array}$ \\
$\begin{array}{l}\text { News story } \\
\text { analysis }\end{array}$ & 6 & $\begin{array}{l}\text { "This article seems to only have the voices of the protestors in } \\
\text { Brooklyn not mentioning the grand jury's reason or police's reason } \\
\text { for it marginalizing the grand jury and police in this case." }\end{array}$ \\
$\begin{array}{l}\text { Literary } \\
\text { analysis }\end{array}$ & 11 & $\begin{array}{l}\text { "Self reliance and individualism were key beliefs of } \\
\text { transcendentalists because an independent person has the ability to } \\
\text { think for himself" }\end{array}$ \\
$\begin{array}{l}\text { Twitter } \\
\text { reflection }\end{array}$ & 2 & $\begin{array}{l}\text { "I think this Twitter thingy's a great way to keep up with class as a } \\
\text { whole. No more HW lag you guys." }\end{array}$ \\
\hline
\end{tabular}

approximately 20 minutes each. The teacher asked students to briefly explain how well they felt they could complete seven essential critical literacy skills: identifying an author's viewpoint; interpreting an author's viewpoint; determining what the author wants them to think; determining whose voices are missing, silenced, and/or discounted in a text; determining perspectives alternative to the author; using alternative perspectives to gain a broader understanding of the text; and taking a form of action based on a critical understanding of a text.

\section{Data Analysis}

Data were analyzed with a qualitative conventional content analysis approach $^{3}$ in order to facilitate emergence of essential content and make inferences addressing the context of the guiding research question (Krippendorff, 2004). Data included 326 student assignment tweets, 217 pages of student reflections, nine pages of teacher reflections, 14 pages of student focus group transcripts, and six pages of student interview transcripts. Both researchers began analysis by reading through the entirety of the data to reach a point of immersion. Upon doing so, preliminary codes were created to capture the essence of the data in one to five

${ }^{3}$ A method of qualitative data analysis in which initial coding categories emerge from the text without the guide of an underlying theory (Krippendorff, 2004). 
words. This was followed by a second cycle of coding to rearrange and revise the initial codes to achieve a more robust and mature series of codes. These finalized codes were grouped by similarity and pattern to develop emergent categories. At this point inter-rater reliability was checked and determined to be .90 . Finally, similar categories were combined in reference to the research question to develop greater meanings, which were presented as themes (Saldana, 2012).

Table 2

\section{Assignment Tweet Prompts}

\begin{tabular}{|c|c|c|c|}
\hline Tweet & Prompt & Tweet & Prompt \\
\hline 1 & $\begin{array}{l}\text { Make a prediction about the } \\
\text { effectiveness of using Twitter in the } \\
\text { classroom. }\end{array}$ & 11 & $\begin{array}{l}\text { Your first impression of One Flew } \\
\text { Over the Cuckoo's Nest }\end{array}$ \\
\hline 2 & $\begin{array}{l}\text { What are potential problems with } \\
\text { using Twitter in the classroom? }\end{array}$ & 12 & $\begin{array}{l}\text { Explain one big idea or quote from } \\
\text { "Self-Reliance." }\end{array}$ \\
\hline 3 & $\begin{array}{l}\text { Explain your initial understanding } \\
\text { of Transcendentalism. }\end{array}$ & 13 & $\begin{array}{l}\text { Which critical literacy most applies to } \\
\text { "Self-Reliance"? Why? }\end{array}$ \\
\hline 4 & $\begin{array}{l}\text { Make a personal connection with } \\
\text { one of the elements of } \\
\text { Transcendentalism. }\end{array}$ & 14 & $\begin{array}{l}\text { Apply one element of critical literacy } \\
\text { to a recent news story. }\end{array}$ \\
\hline 5 & $\begin{array}{l}\text { Tweet one big idea or quote from } \\
\text { today's reading on an overview of } \\
\text { Transcendentalism. }\end{array}$ & 15 & $\begin{array}{l}\text { Apply critical literacy to Cuckoo's } \\
\text { Nest. }\end{array}$ \\
\hline 6 & $\begin{array}{l}\text { After the five-minute exploration on } \\
\text { Twitter, explain one new thing } \\
\text { you've learned about } \\
\text { Transcendentalism. }\end{array}$ & 16 & $\begin{array}{l}\text { How can critical literacy be important } \\
\text { in your life? }\end{array}$ \\
\hline 7 & $\begin{array}{l}\text { Apply one element of critical } \\
\text { literacy to a recent news story. }\end{array}$ & 17 & $\begin{array}{l}\text { Tweet an important or interesting } \\
\text { Cuckoo's Nest quote. }\end{array}$ \\
\hline 8 & $\begin{array}{l}\text { Tweet a quote that you think is } \\
\text { important from "Nature." Then, } \\
\text { reply to your own Tweet to explain } \\
\text { its importance. }\end{array}$ & 18 & $\begin{array}{l}\text { Tweet an important idea or quote from } \\
\text { "Civil Disobedience." }\end{array}$ \\
\hline 9 & $\begin{array}{l}\text { Apply one element of critical } \\
\text { literacy to a recent news story. }\end{array}$ & 19 & $\begin{array}{l}\text { Apply critical literacy to "Civil } \\
\text { Disobedience." }\end{array}$ \\
\hline 10 & $\begin{array}{l}\text { Apply critical literacy to the story of } \\
\text { the First Thanksgiving. }\end{array}$ & 20 & $\begin{array}{l}\text { Take an action step with critical } \\
\text { literacy. }\end{array}$ \\
\hline
\end{tabular}

Additionally, the teacher randomly selected six students for semistructured interviews. Each student was asked to describe his or her experience during the unit, and they lasted approximately 15 minutes each. All student 
interviews and focus groups were conducted, recorded, and transcribed by the teacher, and they all occurred within his classroom.

\section{Researcher Roles}

The lead researcher also played the role of the teacher and in doing so, he created and implemented all lesson plans. Additionally, the teacher/lead researcher collected all data. As the teacher, the lead researcher had a vested interest in the teaching and learning of the 32 student-participants. This interest included a desire to see Twitter successfully used in the class. This type of interest, which is natural among teachers in an action research study, inherently limits the objectivity of the researcher in data collection and analysis. However, the co-researcher helped to maintain objectivity in her significant role in analyzing data and interpreting results because she had no vested interest in student success in the study.

\section{RESULTS}

Four significant themes emerged from the six data sources: transformation of teaching and learning, amplified student voice, increased student engagement, and potential for action. Table 3 displays each theme along with a significant statement that is representative of the data and a formulated meaning that interprets the statement in the context of the theme.

\section{Transformation of Teaching and Learning}

Twitter was found to transform the way the teacher taught and students learned in the classroom. It enabled the teacher to increase the pace of lessons and prevent downtime in class. The teacher often used Twitter as a type of instructional transition into and between direct instruction, reading, writing, and discussion. Because Twitter facilitated easy, fast access to engaging, bite-size pieces of information, not only did it transition from one instructional mode to another, it served as a mode of instruction itself. One student expressed, "I like posting or retweeting quick things! It's a fast and easy way to share what we learn."

Table 3

Themes, Significant Statements, and Formulated Meanings in Student Tweets

\begin{tabular}{lll}
\hline Themes & Significant Statements & Formulated Meaning \\
\hline $\begin{array}{l}\text { Transformation } \\
\text { of Teaching } \\
\text { and Learning }\end{array}$ & $\begin{array}{l}\text { "Learning from peers helped to see } \\
\text { other thoughts and incorporate into } \\
\text { [my] own." }\end{array}$ & $\begin{array}{l}\text { Students used peer Tweets on } \\
\text { particular prompts as examples to } \\
\text { formulate their own Tweets. }\end{array}$ \\
$\begin{array}{l}\text { Amplified } \\
\text { Student Voice }\end{array}$ & $\begin{array}{l}\text { "I'm realizing that Twitter is actually } \\
\text { very helpful for discussion and } \\
\text { critical literacy. It's easy to } \\
\text { communicate ideas and helps us to be } \\
\text { concise." }\end{array}$ & $\begin{array}{l}\text { Twitter helped this student to } \\
\text { express herself topics related to } \\
\text { Transcendentalism and critical }\end{array}$ \\
\hline
\end{tabular}




\begin{tabular}{|c|c|c|}
\hline Increased & "I am really enjoying the whole & Twitter helped to make \\
\hline $\begin{array}{l}\text { Student } \\
\text { Engagement }\end{array}$ & $\begin{array}{l}\text { Twitter usage because it is really } \\
\text { making learning about } \\
\text { Transcendentalism in a more modern } \\
\text { way }[\text { sic]." }\end{array}$ & $\begin{array}{l}\text { Transcendentalism more accessible } \\
\text { and relevant to this student. }\end{array}$ \\
\hline $\begin{array}{l}\text { Potential } \\
\text { for Action }\end{array}$ & $\begin{array}{l}\text { "I can take action and apply critical } \\
\text { literacy to outside cases, for example } \\
\text { in the Ferguson case. Why were so } \\
\text { many external voices silenced?" }\end{array}$ & This student was able to question \\
\hline
\end{tabular}

Minimizing downtime and increasing student engagement throughout class allowed for sustained student learning throughout each class period. Learning time was also increased with Twitter use when homework assignment tweets were assigned in addition to normal homework.

Twitter also presented a platform to allow students to learn from their peers. Peer assignment tweets were viewable on each student's Twitter feed, and students were often required to read and respond to classmate tweets. In addition, students were able to learn from Twitter users outside of the classroom by reading their tweets on multiple topics and engaging in dialogue. One student reflected, "Learning from peers helped to see other thoughts and incorporate into [my] own." Another student reflected on how reading peer tweets helped to instill a key critical literacy principal: "Reviewing others' tweets provides alternative perspectives on topics." The teacher further explained, "Students really learned a lot from each other and from the tweets from outsiders. Students learned context faster and could learn from a quick search faster and better than me lecturing." In this last quotation, the teacher referred to the effectiveness of student Twitter use to understand the literature context before reading.

\section{Amplified Student Voice}

Twitter use with critical literacy was found to amplify student voice in the classroom. As Twitter is a technology and mode of communication with which most students felt very comfortable, this confidence, which is often missing from students in formal oral and written communication, allowed them to freely and unreservedly communicate their ideas. One student explained in a reflection, "Using technology allows us to express our feelings," while another student reflected, "I'm realizing that Twitter is actually very helpful for discussion and critical literacy. It's easy to communicate ideas and helps us to be concise." The amplifying effect was especially strong for students who were previously quiet in class, as Twitter provided them with a medium to have their voices heard. This result was recognized and appreciated by many students. One such student reflected, "We were able to hear those less outspoken." The teacher noted this finding in a daily reflection when he described, "One interesting phenomenon that I've noticed in a few students ... is that some students who rarely participate during class time are the most active on Twitter." He later added, "One student participated more on Twitter then she ever has in class." 
Critical literacy's method of questioning and challenging the text combined with the Twitter platform to empower students to play a more active role in their learning, which was often shown by students' readiness to speak critically about each class topic. Students' critical questioning often occurred in class discussion and on Twitter, helping to increase active learning. This stronger student voice could also be seen in their increasing willingness to critically question texts and the teacher. One student reflected on her view of the importance of critical literacy: "Critical literacy is important in life because it allows us to question things and not just go with the flow because someone told us that's the way things have to be." This student expressed her understanding that she was not obliged to be a passive learner, but that she could use questioning to actively participate in her education. The teacher further reflected on the way Twitter added to students' active role: "Twitter seems to provide students with additional power in the classroom because they have a greater ability to guide their own learning (i.e., five-minute explorations) and serve as experts in the use of technology." The power that the teacher mentioned again refers to students' active role in their learning, while their expert technology use refers to their high skill level in using Twitter.

\section{Increased Student Engagement}

Students were found to be highly engaged throughout most of the unit as a result of their use of Twitter to apply critical literacy to various texts and concepts. The researchers defined high student engagement as high levels of student attention, interest, and participation in class content, and this phenomenon occurred from the start of the unit. The teacher described this in the post-unit interview: "Students were initially very excited to use Twitter. As the excitement wore off, the engagement remained. Integrating Twitter into the lessons provided me with another tool to keep things interesting through the 55 minutes of each class." The student excitement that the teacher described came from students' use of cell phones and Twitter, as this was not normally allowed in class. But once the novelty of the technology passed, students continued to enjoy using Twitter with tasks related to critical literacy and Transcendentalism. One student commented, "It's cool that we can use Twitter to search up any of the people or their works that relate to Transcendentalism." Another added, "I am really enjoying the whole Twitter usage because it is really making learning about Transcendentalism in a more modern way."

The teacher also learned to use Twitter as an instructional tool within a lesson to increase engagement when he felt it was lagging. He attempted to be strategic with Twitter use, as he found that each instance of use took about five minutes of class time. Initially the time was spent silently while students were absorbed with creating a tweet on a prompt and reading others' tweets. However, the teacher reflected that to avoid a room full of students digitally isolated and "engrossed in the technology," he began to require all in-class tweets to be followed by a partner, then whole-class discussion. As students tweeted and shared, the teacher provided feedback by reading through tweets, repeating some good examples aloud, and replying to others on Twitter. In addition, the co-researcher 
often read through student tweets and replied to students to increase out-of-class communication. The teacher found that this student, teacher, and researcher feedback resulted in further student engagement. One student reflected, "I want more principal people to reply to my tweets, it makes me feel smart." This type of feedback also facilitated greater interactivity inside and outside of the classroom, as students were compelled to communicate with each other, the teacher, and others outside of the classroom on the curriculum, and this interactivity fueled further engagement. One student explained, "It kind of reminds me of a Socratic seminar online, the way everyone pays attention and adds something into the overall conversation."

\section{Potential for Action}

Students often had difficulty in taking action steps with critical literacy. When asked how one could take a critical literacy action step with Twitter, most students were successful in completing the task. For example, one student explained that critical literacy "can be used to question the motives of authoritative figures. It's important to analyze whether their orders/actions are meant to hurt you, or if they're for your own good. Parents and police officers are major subjects of this." However, when students were asked to follow through with an action step, many simply did not complete the assignment. After failing to tweet on this assignment, one student reflected, "I don't know how to apply action to this scenario." Another common type of a response was to substitute the action step for the simpler task of describing a possible action. This was seen when a student tweeted, "I can take action and apply critical literacy to outside cases, for example in the Ferguson case. Why were so many external voices silenced?" While this student applied an important critical question to the news story involving the controversial shooting of Michael Brown in Ferguson, Missouri, it fell short of taking action. In response to such student attempts at action steps, the teacher reflected, "When they were required to actually take the step, they greatly struggled." However, some were able to succeed, as evidenced by one student's tweet:

Society has a lot of hygienic and cosmetic expectations of women, but they're unrealistic, unfair, and impractical, not to mention somewhat sexist. Any views that challenge the status quo [are] generally ignored. I've decided to stop shaving my legs in response to this. Even though it's winter now, I'm going to see how long I can keep it up, even into shorts season. And I don't care what anyone will think of it, because I'm taking action about something I care about.

This particular student was able to apply critical literacy skills by questioning a societal expectation of women to take an action step, using Twitter to communicate the action.

\section{DISCUSSION}




\section{Theme 1: Transformation of Teaching and Learning}

The first major theme, transformation of teaching and learning, consists of the way Twitter and critical literacy changed the nature of teaching and learning in the classroom of study. The teacher found Twitter to optimize learning time by increasing the pace of each class period and decreasing downtime-something that helped to sustain student focus on learning. In high school, class periods often consist of approximately 60 minutes, but this does not mean student learning occurs for the entire time. Although it is difficult to determine the proportion of each class period that students are engaged in learning, it is safe to say that most teachers can increase the amount of learning time each period. Decreased downtime and increased focus can mean more daily learning, and when compounded over the course of an entire school year, this can potentially result in significant learning gains. Perhaps this is even more important when one considers the inherent time limitations placed on English teachers to teach the numerous standards each year. While research findings are mixed on the relationship between learning time and student achievement, the past 30 years has shown an upward trend in the minimum number of state-required school days in the academic year (Woods, 2015). Rogers and Mirra (2014) explained that learning time is so important that its inequitable use in California high schools is a contributing factor in the income achievement gap.

Additionally, Twitter seems to be an effective tool to facilitate peer learning, providing dual affordances. A number of studies, in settings from elementary school through higher education, have found peer modeling to facilitate student learning (Ledford \& Wolery, 2013; Murphy, 2015; Richards, Heathfield, \& Jenson, 2010; Urlacher, Wolery, \& Ledford, 2016). In the present study, Twitter was found to facilitate peer modeling, in which students were able to learn from peer tweets, helping them to better understand assignments or to compare their own work as a measure of adequacy. Peer modeling was especially helpful to students when dealing with the unfamiliarity and challenge of critical literacy and developing a critical literacy competency. This was similar to the results of Casey and Wells (2015), who found peer modeling, in addition to peer feedback and peer assessment, to be an affordance of social media in the high school classroom. Gan, Menkhoff, and Smith (2015) also found that the collaborative nature of web-based teaching and learning enables students to attain deeper learning with the help of their peers.

A second affordance was the exercise and practice of the critical literacy tenet examining multiple perspectives, in which students compared their own perspectives to peers on class topics ranging from American Transcendentalist literature to current events. As Twitter provides students with the opportunity to rapidly view multiple perspectives, students were able to practice this important skill that is prerequisite to applying critical literacy. While Twitter use is no surefire path to multiple perspective examination, as it is possible for users of social media to simply reaffirm existing biases, it is the platform for examination that is most valuable to teaching critical literacy. 


\section{Theme 2: Amplified Student Voice}

The theme amplified student voice comprises students' comfort and newly developed confidence using Twitter to articulate their ideas through critical literacy. This finding is of especial interest because of insecurities and apprehensiveness common among high school students when speaking on curricular topics in front of a class and, in particular, to their teachers. While this reticence may induce the assumption that students have nothing to say, it seems instead that they simply lack the means to convey their thoughts. Ralph Waldo Emerson (1841/1981), the leader of the American Transcendentalist movement, spoke of a similar phenomenon over 150 years ago in his essay "Self-Reliance" when he remarked,

Do not think the youth has no force, because he cannot speak to you and me. Hark! in the next room his voice is sufficiently clear and emphatic. It seems he knows how to speak to his contemporaries. Bashful or bold, then, he will know how to make us seniors very unnecessary. (140)

Twitter seems to be a technology that can facilitate students' ability to communicate on academic topics to "you and me," and by doing so, it can empower students to use their voice and be heard. Twitter was also found to promote equity of student voice in the classroom. Through the use of Twitter, students were able to achieve an equal voice regardless of their personality type, as extroverts had no advantage over introverts in communicating their thoughts and learning. As a result of an amplified student voice, students appear better able to speak what Freire (1970) described as the true word, which he explained as a combination of reflection and action. This true word can facilitate dialogue among students and between students and the teacher. Ultimately, according to Freire, dialogue is essential to making a positive change in the world.

\section{Theme 3: Increased Student Engagement}

The third theme is, to a certain extent, a consequence of the previous two. The transformation of teaching and learning and the amplification of student voice facilitated student engagement, and, in turn, engagement further fed transformation and student voice. Twitter seemed to be the initial driver of engagement, as it helped to hook and motivate students into learning about critical literacy and American Transcendentalism-two challenging topics. Twitter made the topics more relevant for students, and once it brought students across the threshold of unfamiliarity, their interest was then sustained by the allure and merits of critical literacy and American Transcendentalism. These engagement findings are similar to those of Igbo, Ezenwaji, and Ajuziogu (2018); Junco et al. (2011, 2013); and Williams and Whiting (2016), who found academic use of Twitter among secondary and college classrooms to have positive effects on engagement.

Additionally, the increased student-student and student-teacher communication that was a part of the engagement experience in this study strengthened classroom relationships and increased the sense of classroom 
community. Similar results were found by Veira, Leacock, and Warrican (2014), who found information and communications technology to facilitate interaction of high school students among peers and with their teacher, and Rohr and Costello (2015), who found Twitter to increase students' feeling of connectedness in a large online college course. Notably, the current study's findings were not a simple consequence of bringing technology into the classroom. As described in the results, students' initial response to Twitter use in the classroom was to become more isolated, as opportunities that normally led to peer interaction and discussion were replaced with Twitter use. It was after the teacher intervened by requiring additional peer face-to-face communication with each Twitter use that relationships began to strengthen and surpass the state of classroom community seen before Twitter and critical literacy implementation. This form of relationship building seems to be especially important in an AP course, as students' greater focus on class rank and college prospects often leads to greater competition and self interest. This theme of increased student engagement also helped to develop the teacher-student partnership that Freire (1970) described as essential in the classroom to dispel old notions of banking education and instead work towards a liberating education. Importantly, increased classroom community and stronger partnerships move students to become "critical co-investigators in dialogue with the teacher" (Freire, 1970, 81).

\section{Theme 4: Potential for Action}

Finally, the theme potential for action represents students' latent critical literacy action. Action steps, as previously described, are a major goal of critical literacy, as they can be used as a measure of success of critical literacy implementation. Because taking action on American Transcendentalism proved to be a difficult student task, the teacher shifted the Twitter focus of this skill to relevant news stories and social issues to maximize students' potential success. While students were often successful in developing a theory of action on news stories they discovered on Twitter, they largely struggled to follow through with action steps-limitations similar to those described by Bishop (2014) and Phelps (2010). It seems that the classroom presents certain restraints and limitations that may deter many forms of action - most notably students' sense of impotence and passivity formed by years spent in a traditional education system (Freire, 1970). However, Twitter and other social media have changed the nature of communication, those capable of taking action, and likely, the very conception of action. In recent history the world has witnessed Twitter's role in new forms of action unimaginable even a decade ago. This was seen in the Arab Spring, as citizens of Tunisia and neighboring Arab nations used Twitter to communicate democratic ideals and organize protests, contributing to the toppling of oppressive regimes. We also witnessed Donald Trump use Twitter as his choice method of communication with the general public, helping him to win the 2016 presidential election and become the 45th president of the United States. So perhaps it is time to reconceive the meaning of action steps in critical literacy. 
In this study, Twitter facilitated student communication of critical literacy principles applied to American Transcendentalist literature and current events. This work enabled students to approach, and in some cases attain, creation of Freire's (1970) concept of the true word. The true word, in turn, was used to engage in dialogue, something Freire described as "the encounter between men, mediated by the world, in order to name the world" (p. 88). Thus despite students' struggles to attain traditional action steps, the true word and subsequent dialogue is a praxis and by definition an action step. So despite most students' inability to achieve traditional action steps, it seems they were able to achieve what may be termed as critical action - that is, an act applying critical literacy theory with the intent to liberate. Additionally and perhaps most importantly, critical literacy, through the use of Twitter, has moved students towards critical consciousness. Likely, persistent practice and continued liberation from traditional forms of oppressive education through the teacher-student partnership can result in a true state of critical consciousness.

\section{Limitations and Recommendations}

This study used an action research method of inquiry, as the teacher in the study was also the lead researcher. This inherently limited the objectivity of the study because of the teacher's interest in the success of his students. But because the co-researcher was not directly involved in the classroom and was not an educator in the school district, bias in data analysis was limited. On a similar note, a potential source of bias arose in data collection, as the teacher collected all of the student data and it is conceivable that students considered possible grade implications based on the type of responses that they made. Additionally, while the researchers chose an AP class to reduce or eliminate variables such as poor behavior and inattention, these targeted students were less likely to benefit from critical literacy skills compared to lower-achieving students who often come from low-income households. Future studies should target low-achieving students and low-income students to better epitomize the spirit and values of Freirean liberatory education.

Generalizability of results is limited for several reasons. Firstly, this was a case study design, and the results found for this class are not necessarily replicable in other settings. Secondly, the class of study was of an AP level, and results may not extend to other class levels. This limitation includes two major considerations: Compared to other students, it is often true that AP students exhibit higher levels of intrinsic motivation and require less classroom management. Finally, this study occurred over the course of one month, which is less optimal than one occurring over the course of a semester or an entire school year. To increase generalizability of findings, future studies may replicate the current study over an entire marking period using an experimental mixed methods design, a larger sample size, and multiple class levels. Additionally, future studies may find success in attaining traditional critical literacy action steps by using Twitter to focus solely on current events and timely social issues. 


\section{CONCLUSIONS}

To address previous literature citing teachers' difficulties implementing critical literacy and enabling students to attain action steps, this study sought to explore the affordances of Twitter as a tool to apply critical literacy to a unit of American Transcendentalist literature. Multiple affordances were found; but first and foremost, Twitter was found to be an effective tool in implementing critical literacy in the classroom. In doing so, Twitter helped to transform teaching and learning by optimizing learning time and facilitating peer learning. Additionally, Twitter was found to amplify student voice, allowing students to confidently communicate about literature and critical literacy prompts. In particular, the voices of introverted students were found to be especially enabled. Twitter also increased student engagement, making it easier for the teacher to teach the challenging critical literacy skills and facilitate strong, content-specific dialogue that led to a greater sense of community. Finally, Twitter helped students to approach traditional forms of action and move toward a state of critical consciousness. But perhaps more importantly, it enabled them to achieve critical action, in which students applied critical literacy theory to communication, in the form of tweets, on current events and social issues that resulted or had the potential to result in a subsequent positive impact on their lives or the lives of others.

As young people's lives are bombarded with more information than ever before, educators should strongly consider teaching students critical literacy skills as a defense mechanism against the nefarious purposes of many types of information. Twitter is not only a practical means of implementing critical literacy, it is also a good opportunity to teach effective social media use from a critical perspective. Otherwise, instead of serving as a tool for potential liberation as was seen in the Arab Spring, social media may simply become another tool for societal oppression.

\section{REFERENCES}

Barber, L., Sevastopulo, D., \& Tett, G. (2017, April 2). Donald Trump: Without Twitter, I would not be here-FT interview. Retrieved from https://www.ft.com/content/943e322a-178a-11e7-9c35-0dd2cb31823a

Barbour, M., \& Plough, C. (2009). Social networking in cyberschooling: Helping to make online learning less isolating. TechTrends, 53(4), 56-60.

Behrman, E. H. (2006). Teaching about language, power, and text: A review of classroom practices that support critical literacy. Journal of Adolescent \& Adult Literacy, 49(6), 480-488.

Bishop, E. (2014). Critical literacy. Journal of Curriculum Theorizing, 30(1), 51-63.

Bloome, D., Carter, S. Christian, B. Otto, S., \& Shuart-Faris, N. (2004). Discourse analysis and the study of classroom language and literary events: A microethnographic perspective. Mahwah, NJ: Routledge.

Bower, M. (2008). Affordance analysis - matching learning tasks with learning technologies. Educational Media International, 45(1), 3-15. 
Casey, G., \& Wells, M. (2015). Remixing to design learning: Social Media and peer-to-peer interaction. Journal of Learning Design, 8(1), 38-54.

Comber, B. (2011). Changing literacies, changing populations, changes places English teachers' work in an age of rampant standardization. English Teaching: Practice and Critique 10(4), 5-22.

Creswell, J. W. (2007). Qualitative inquiry and research design: Choosing among five approaches ( ${ }^{\text {nd }}$ ed.). Thousand Oaks, CA: SAGE Publications.

Emerson, R. W. (1981). Self-reliance. In C. Bode\& M. Cowley (Eds.), The portable Emerson (pp. 138-164). New York: Penguin Books. (Original work published in 1841).

Ferrance, E. (2000). Themes in education: Action research. Providence, RI: Brown University.

Freire, P. (1970). Pedagogy of the oppressed. New York: Continuum.

Freire, P. (1974). Education for critical consciousness. New York: Seabury Press.

Freire, P., \& Macedo, D. (1987). Literacy: Reading the word and the world. MA: Bergin \& Garvin Publishers, Inc.

Gan, B., Menkhoff, T., \& Smith, R. (2015). Enhancing students' learning process through interactive digital media: New opportunities for collaborative learning. Computers in Human Behavior, 51, 652-663.

Gee, J. P. (1989). Literacy, discourse, and linguistics: Introduction. The Journal of Education, 171(1), 5-17.

Gee, J. P. (2000). The new literacy studies. From the "socially situated" to the work of the social. In D. Barton, M. Hamilton, \& R. Ivanic (Eds.), Situated literacies: Reading and writing in context (p. 180 - 196). London: Routledge.

Gee, J. P. (2002). Social linguistics and literacies: Ideology in discourse (2nd ed.). New York: Routledge.

Gee, J. P. (2005). An introduction to discourse analysis: Theory and method. New York: Routledge.

Igbo, J. N., Ezenwaji, I., \& Ajuziogu, C. U. (2018). Facebook, Twitter activities sites, location and students' interest in learning. International Education Studies, 11(2), 133-143.

Junco, R., \& Chickering, A. W. (2010). Civil discourse in the age of social media. About Campus, 15(4), 12-18.

Junco, R., Elavsky, C. M., \& Heiberger, G. (2013). Putting Twitter to the test: Assessing outcomes for student collaboration, engagement and success. British Journal of Educational Technology, 44(2), 273-287.

Junco, R., Heiberger, G., \& Loken, E. (2011). The effect of Twitter on college student engagement and grades. Journal Of Computer Assisted Learning, 27(2), 119-132.

Kassens, A. L. (2014). Tweeting your way to improved \#writing, \#reflection, and \#community. The Journal of Economic Education, 45(2), 101-109.

Krippendorff, K. (2004). Content analysis: An introduction to its methodology. Thousand Oaks, California: SAGE Publications. 
Krutka, D., \& Milton, M. K. (2013). The Enlightenment meets Twitter: Using social media in the social studies classroom. Ohio Social Studies Review, 50(2), 22-29.

Ledford, J. R., \& Wolery, M. (2013). Peer modeling of academic and social behaviors during small-group direct instruction. Exceptional Children, 79(4), 439-458.

Lee, C. J. (2011). Myths about critical literacy: What teachers need to unlearn. Journal of Language and Literacy Education [Online], 7(1), 95-102. Available at http://www.coa.uga.edu/jolle/2011_1/lee.pdf

Luke, A. (2000). Critical literacy in Australia: A matter of context and standpoint. Journal of Adolescent \& Adult Literacy, 43(5), 448-461.

Machado, C., \& Jiang, Y. (2014). Using Twitter to heighten student engagement, critical thinking, and reflective practice within and beyond the classroom. Teacher Education and Practice, 27(4), 577-590.

Margaryan, A., Littlejohn, A., \& Vojt, G. (2010). Are digital natives a myth or reality? University students' use of digital technologies. Computers \& Education, 56(2), 429-440.

McLaughlin, M., \& DeVoogd, G. (2004a). Critical literacy: Enhancing students' comprehension of text. New York: Scholastic.

McLaughlin, M., \& DeVoogd, G. (2004b). Critical literacy as comprehension: Expanding reader response. Journal of Adolescent \& Adult Literacy, 48(1), 52-62.

McLeod, J., \& Vasinda, S. (2008). Critical literacy and Web 2.0: Exercising and negotiating power. Computers in the Schools, 25(3/4), 259-274.

Menkhoff, T., Chay, Y. W., Bengtsson, M. L., Woodard, C.J., \& Gan, B. (2015). Incorporating microblogging ("tweeting") in higher education: Lessons learnt in a knowledge management course. Computers in Human Behavior, 51, 1295-1302.

Mishra, P., \& Koehler, M. J. (2006). Technological pedagogical content knowledge: A framework for teacher knowledge. Teachers College Record, 108(6), 1017-1054.

Morrell, E. (2005). Toward a critical English education: Reflections on and projections for the discipline. English Education, 37, 312-322.

Murphy, C. (2015). The use of peer modeling to increase self-efficacy in research methods courses. Journal of Political Science Education, 11(1), 78-93.

National Education Associaton.(2010). Preparing 21st century students for a global society: An educator's guide to the "four Cs." Retrieved from http://www.nea.org/assets/docs/A-Guide-to-Four-Cs.pdf

New London Group (1996). A pedagogy of multilitericies: Designing social futures. Harvard Educational Review, 66(1), 60-92.

Palinkas, L. A., Horwitz, S. M., Green, C. A., Wisdom, J. P., Duan, N., \& Hoagwood, K. (2015). Purposeful sampling for qualitative data collection and analysis in mixed method implementation research. Administration and Policy in Mental Health, 42(5), 533-44. 
Phelps, S. (2010). Critical literacy: Using nonfiction to learn about Islam. Journal of Adolescent and Adult Literacy, 54(3), 190-198.

Prensky, M. (2001). Digital natives, digital immigrants. On the Horizon, 9(5), 1-6.

Project Look Sharp. (2018). What is project look sharp? Retrieved from https://www.projectlooksharp.org/

Rheingold, H. (2009). Twitter literacy (I refuse to make up a Twittery name for it). Retrieved from https://blog.sfgate.com/rheingold/2009/05/11/twitterliteracy-i-refuse-to-make-up-a-twittery-name-for-it/

Rogow, F. (2011). Ask, don't tell: Pedagogy for media literacy education in the next decade. Journal of Media Literacy Education, 3(1), 16-22.

Richards, L. C., Heathfield, L. T., \& Jenson, W. R. (2010). A classwide peermodeling intervention package to increase on-task behavior. Psychology in the Schools, 47(6), 551-566.

Rideout, V. J., Foehr, U. G., \& Roberts, D. F. (2010). Generation M2: Media in the lives of 8- to 18-year-olds. Kaiser Family Foundation. Retrieved from http://www.kff.org/entmedia/mh012010pkg.cfm

Riley, K. (2015). Enacting critical literacy in English classrooms: How a teacher learning community supported critical inquiry. Journal of Adolescent \& Adult Literacy, 58(5), 417-425.

Rogers, J., \& Mirra, N. (2014). It's about time: Learning time and educational opportunity in California high schools. Los Angeles, CA: UCLA IDEA.

Rohr, L., \& Costello, J. (2015). Student perceptions of Twitter's effectiveness for assessment in a large enrollment online course. Online Learning, 19(4), 2536.

Saldana, J. (2012). The coding manual for qualitative researchers. Los Angeles, CA: SAGE.

Smith, A., \& Anderson, M. (2018). Social media use in 2018. Pew Research Center.

Smith, W. A. (1976). The meaning of conscientização: The goal of Paulo Freire's pedagogy. Amherst, MA: Center for International Education.

Sperry, C., \& Baker, F. W. (2016). Media literacy. Social Education, 80(3), 183185.

Statistica (2018). Distribution of Twitter users in the United States as of December 2016, by age group. Retrieved from https://www .statista.com/statistics/192703/age-distribution-of-users-ontwitter-in-the-united-states/

Street, B. (2003). What's "new" in new literacy studies? Critical approaches in theory and practice. Current Issues in Comparative Education, 5(2), 77-91.

Stribling, S. M. (2008). Using critical literacy practices in the classroom. The NERA Journal, 44(1), 34-38.

Stringer, E. T. (1999). Action research (2 $2^{\text {nd }}$ ed.). Thousand Oaks, CA: SAGE Publications.

Thompson, P. (2013). The digital natives as learners: Technology use patterns and approaches to learning. Computers \& Education, 65, 12-23.

Tsukayama, H. (2017, November 7). Twitter is officially doubling the character limit to 280. The Washington Post. Retrieved from 
www.washingtonpost.com/news/the-switch/wp/2017/11/07/twitter-isofficially-doubling-the-character-limit-to280/?noredirect=on\&utm_term $=. e 22307589 b 0 a$.

Twitter. Company facts. (2016, June 30). Retrieved from https://about.twitter.com/company

Urlacher, S., Wolery, M., \& Ledford, J. R. (2016). Peer modeling of commenting during small group direct instruction for academic behaviors. Journal of Early Intervention, 38(1), 24-40.

Veira, A. K., Leacock, C. J., \& Warrican, S. J. (2014). Learning outside the walls of the classroom: Engaging the digital natives. Australasian Journal of Educational Technology, 30(2), 227-244.

Waycott, J., Bennett, S., Kennedy, G., Dalgarno, B., \& Gray, K. (2010). Digital divides? Student and staff perceptions of information and communication technologies. Computers \& Education, 54(4), 1202-1211.

Williams, D., \& Whiting, A. (2016). Exploring the relationship between student engagement, Twitter, and a learning management system: A study of undergraduate marketing students. International Journal of Teaching and Learning in Higher Education, 28(3), 302-313.

Woods, J. R. (2015, August). Education trends: Instructional time trends. Denver, CO: Education Commission of the States. 